\title{
Evaluation of the effect of estrogen on left ventricular remodeling in the rat model
}

\author{
Lobna Abdel Aal Kassem, Zeinab Abdel Hafeez Alrefaie \\ and Moshira Abdel Hakim Rateb \\ Department of Physiology, Kasr Al Aini Faculty of Medicine, \\ Cairo University
}

\begin{abstract}
The aim of the present study was to investigate whether estrogen plays a role in remodeling of the left ventricle in the hearts of female rats. Four groups of animals were studied: control group, ovariectomized group, ovariectomized receiving estrogen treatment for 4 weeks and lastly ovariectomized animals receiving both estrogen and the protein kinase $C$ inhibitor chelerythrene for 4 weeks.

At the end of the four weeks period, the animals were sacrificed and left ventricular performance, left ventricular axis, left ventricular weight and heart weight were measured. The ventricular tissue level of metalloproteinase 9 (MMP-9) and the expression of collagen type I and angiotensin II type I receptors (AT1) were also assessed.

Results of this work show that ovariectomy induced a reduction in left ventricular pressure, an increase in left ventricular axis, left ventricular weight and total heart weight as compared to sham operated group $(P<0.05)$. The animals also showed an increased expression of collagen type I, AT1 receptors and increased level of MMP- 9 in ventricular tissue samples. Estrogen supplementation in ovariectomized animals improved the mechanical performance of the heart as evidenced by significant increase of left ventricular pressure, heart rate and dp/dt towards normal levels. It also reduces left ventricular hypertrophy and dilatation as significant reduction of left ventricular axis, left ventricular weight and heart weight towards control levels were observed. Furthermore, estrogen reduced the expression of collagen type I \& AT1 receptors as well as the level of MMP-9 in ventricular tissues $(P<0.05)$. Treatment of ovariectomized animals with both estrogen and the protein kinase $C$ inhibitor chelerythrene (group IV) resulted in partial block of the cardioprotective effect of estrogen treatment alone (group III).

We conclude that estrogen, possibly through a mechanism that involves protein $C$ activation, seems to reduce left ventricular hypertrophy and dilatation as well as left ventricular tissue level of MMP- 9 and expression of collagen type I \& AT1 receptors while maintaining left ventricular pressure and performance. Such results suggest a positive role of estrogen in cardiac protection in female rats through regulating certain Key elements involved in the process of ventricular remodeling.
\end{abstract}

Key words: Estrogen, left ventricle remodeling, angiotensin II receptors, metalloproteinases, collagen, protein kinase $C$. 


\section{INTRODUCTION}

Ventricular remodeling is the process by which mechanical, neurohormonal, and possibly genetic factors alter ventricular size, shape, and function. Hallmarks of remodeling include hypertrophy and modifications of the contractile machinery of cardiac myocytes as well as alteration in the extra-cellular matrix leading to collagen accumulation $^{(\mathbf{1})}$. This accumulation reflects disturbance in the balance between collagen deposition and collagen degradation by matrix metallo-proteinases ${ }^{(2)}$.

Such changes promote fibrosis and ventricular stiffness which may cause electrical and mechanical alterations thus resulting in predisposition to heart failure, arrythmias and sudden death ${ }^{(\mathbf{1})}$.

Angiotensin II (Ang II) is now accepted as a key player in the process of myocardial remodeling. Experimental and clinical evidence is providing support for the notion that this peptide induces myocardial fibrosis, which is the result of the exaggerated deposition of collagen types I and III fibers and as a consequence of the predominance of synthesis over degradation of collagen molecules. The interaction of Ang II with the Ang II type-1 $\left(\mathrm{AT}_{1}\right)$ receptor located in cardiac fibroblasts is one of the potential pathways that mediate the profibrotic effects of Ang II on the heart $^{(3)}$.

The matrix metalloproteinases (MMPs) play an important role in ventricular remodeling as they are characterized by their ability to degrade the extracellular matrix proteins (ECM). This family of proteolytic enzymes includes nowadays at least 20 enzymes. Several lines of evidence suggest a fundamental role for myocardial MMP-9 in LV remodeling ${ }^{(4)}$.

Aging is also associated with increased heart remodeling, however, gender seems to play a role in how our hearts respond to the aging process. Premenopausal women are much less prone to develop cardiovascular disease than men of similar age, but this advantage no longer applies after women reach menopause suggesting that estrogen has a cardio-protective effect $^{(5)}$. It is equally conceivable that molecular differences exist between sexes in the LV remodeling process. Investigators have reported sexrelated differences in remodeling at the cardiomyocyte level, influenced partly by MMP activation. However, the intracellular signalling is still unclear $^{(\mathbf{6})}$

However, the proposed positive effect of estrogen on cardiac performance has been lately challenged by the recent Women's health initiative study which evaluated the effects of estrogen alone or estrogen plus progestins in postmenopausal women. The initiative found significant negative cardiovascular outcomes of such interventions that led to the discontinuation of this part of the study $^{(7)}$. It seems that estrogens are implicated in both worsening and protecting from cardiovascular disease through the regulation of a plethora of pathways in the cardiac tissue including possibly the local renin angiotensin system $^{(8)}$. 
The aim of this study was to investigate the effects of estrogen on myocardial remodeling and performance. We thought to determine whether 17 beta-estradiol alters the expression of type I collagen, the major fibrillar collagen in the heart, and angiotensin type 1 receptor as well as its effect on the activity of MMP-9. This aim is achieved through the evaluation of the effects of ovariectomy with or without estrogen replacement on these mentioned parameters of female rat hearts as well as on their haemodynamic functional parameters. The protein kinase $\mathrm{C}$ inhibitor chelerythrene has been used in conjunction with estrogen in one group to evaluate the possible contribution of protein kinase $\mathrm{C}$ in modulating some of the effects of estrogen on the heart.

\section{MATERIAL \& METHODS}

\section{Animals:}

48 female rats weighing between (150-200 gm) were used in this study and maintained on 12-12 h light dark cycle and allowed free access to normal rat chow and water. All experimental procedures were carried out in accordance with the guidelines on animal care and were approved by the departmental research ethics committee. Rats were randomly divided into four groups:

1. Group I: control animals underwent a sham ovariectomy and received no medications for the length of the protocol. $n=6$.

2. Group II: The animals underwent an ovariectomy at the start of the experimental protocol and received no medications for the length of the protocol (4 weeks). $\mathrm{n}=16$.

3. Group III: The animals underwent a surgical ovariectomy and received estrogen supplementation in the dose of $70 \mathrm{ug} /$ day subcutaneously (SC) for 4 weeks. $n=18$.

4. Group IV: The animals underwent an ovariectomy and received daily $\mathrm{SC}$ estrogen in addition to the Protein kinase $\mathrm{C}$ inhibitor chelerythrene at a dose of $25 \mathrm{ug} / \mathrm{kg}$ body weight given intra-peritoneally (IP) $n=10$

Both estrogen (in the form of 17B estradiol) and chelerythrene were obtained from Sigma as a powder and prepared in distilled water for the required concentrations.

Surgical procedure: Bilateral ovariectomies were performed under anesthesia via a single dorsal incision as previously described ${ }^{(9)}$. Sham operated rats underwent the same procedure, except the ovaries were exteriorized but not removed.

After recovery from anaesthesia, animals in group III and IV were started on regimens of treatment that included either injection of estrogen by $\mathrm{SC}$ injection or estrogen $\mathrm{SC}$ with chelerythrene IP for the period of the study that lasted for four weeks and according to their group allocation.

Isolated rat hearts preparation and perfusion using the Langerdorff apparatus:

After four weeks of treatment, at the end of the experimental protocol, animals were weighed; killed under anesthesia with intra-peritoneal injection of sodium pentobarbital 60 $\mathrm{mg} / \mathrm{kg}$ body weight. The chest wall 
was opened and the heart was dissected along with an attached length of at least $1 \mathrm{~cm}$ of aorta. The heart was rapidly removed and placed in heparinized ice cold Krebs Henseleit bicarbonated buffered solution (in $\mathrm{mM} 118 \mathrm{NaCl}, 4.7 \mathrm{kCl}$, 21 $\mathrm{NaHCO} 3,2.5$

$\mathrm{CaCl}_{2}, 1.2 \mathrm{MgSO}_{4}, 1.2 \mathrm{KH}_{2} \mathrm{PO}_{4}$ and 11 glucose). All solutions were prepared each day with demineralised deionized water and bubbled with $95 \% \mathrm{O}_{2}-5 \% \mathrm{CO}_{2}$ (pH 7.4). The heart was then transferred to the perfusion apparatus where the aorta was cannulated. The cannula was then connected to a reservoir delivering oxygenated mammalian Krebs Henseleit solution at a thermostatically constant temperature $\left(37^{\circ} \mathrm{C}\right)$. The coronary arteries were perfused with retrograde flow through the aortic stump cannula using a constant flow pump of $12 \mathrm{ml} /$ minute. Contractile function was assessed by measuring left intra-ventricular pressure.

For measurements of left ventricular pressure (LVP), a latex balloon was introduced in the left ventricle via the left atrium. The balloon was fixed at the tip of a cannula, which was directly connected to a Gold statum pressure transducer. Pressure changes were then analyzed and displayed on an electronic polygraph (NEC-San-ei Instruments Ltd, 2238). At the beginning of each experiment, the balloon was filled with the perfusion buffer; free from air bubbles to achieve a left ventricular end diastolic pressure (LVEDP) of 5-10 mm Hg. The heart was then allowed to equilibrate for 1530 minutes. Equilibrium was ended when the recorded hemodynamic parameters where maintained at same level for 3 continuous measurement periods timed 5 minutes apart.

Hemodynamic measurements:

The following parameters were measured at the end of the stabilization period

1- Left ventricular systolic pressure (LVSP).

2- Heart rate (HR).

3- Peak rate of left ventricular pressure rise $(\mathrm{dp} / \mathrm{dt})$

Cardiac morphological parameters: At the end of LVP measurements, the hearts were removed from the apparatus, dissected and weighed. The atria were cut away and the right ventricular free wall was carefully dissected from the left. The intraventricular septum was included in measuring the LV weight.

$\mathrm{LV}$ long axis was measured accurately as the distance from atrioventricular valve to the apex and the measurement was used as an index of left ventricular enlargement.

Sample preparation for collagen type I, MMP and AT-1 receptor measurements

Left ventricular tissue was divided into two portions: first portion was stored in lysis buffer that contains guanidinium thiocyanate and B mercaptoethanol for RNA extraction. The second portion was stored at $80^{\circ} \mathrm{C}$. After washing this portion with ice cold saline and homogenizing it, it was lysed on ice in an extraction buffer that contained $10 \mathrm{mmol} / \mathrm{L}$ $\mathrm{K}_{2}$ EDTA, $5 \mathrm{mmol} \quad / \mathrm{ml}$ mercaptoethanol, $0.39 \mathrm{mmol} / \mathrm{L}$ phenyl methyl sulfonyl fluoride and $5 \mathrm{mg} / \mathrm{L}$ aprotenin, $\mathrm{pH} 7.5$ and processed as previously described ${ }^{(\mathbf{1 0})}$. This was 
followed by centrifugation at 20000 rpm for 20 minutes at $4^{\circ} \mathrm{C}$; the supernatant (cell lysate) was frozen at $-80^{\circ} \mathrm{C}$ until analysis of MMP 9 by Elisa system. The assay was carried using MMP -9 Elisa system (Oncogene Research products, USA) for quantification of MMP 9 according to the manufacturers' recommendations.

\section{RNA extraction}

Total RNA was extracted from tissue homogenate by acid guanidium thiocyanate phenol-chloroform then extracted RNA was quantified by spectrophotometer at $260 \mathrm{~nm}$ according to the method described by chomkezynnski and Sacchi (11).

\section{RT-PCR for Collagen -1 and AT-1}

Single strand cDNA was prepared from RNA using the antisense primer as a random primer. The cDNA was made as follows: total RNA was heated at $65^{\circ} \mathrm{C}$ for 5 min with 50 pmol primer before adding 10xRT buffer (50mM trisHCl, pH 8.3,10 mM $\left.\mathrm{mgCl}_{2}, 75 \mathrm{mM} \mathrm{KCl}\right), 2.5 \mathrm{mM}$ dNTPS (promega, Madison) and 40 units murine leukaemia virus reverse transcriptase (pharmacia) in a final volume of $36 \mathrm{ul}$. After incubation at $42{ }^{\circ} \mathrm{C}$ for one hour, the PCR reaction was carried as follows:

An aliquot of cDNA (5uL) was added to $50 \mathrm{pmol}$ of each of sense and antisense primers of collagen -1 : sense -5 CGG GAT CCC GAG CAG ACG GAG-3̀

Antisense 5 TCC CCG GGC GGA GAA CTT ACT G 3

The sense and antisense primers of AT-a1:

Sense -5 AAC TAG CTA TCT CAG GCT TTC 3
Anti-sense 5 ACT TCA GTC TGA ATC TGG CT- 3 with $0.2 \mathrm{mM}$ dNTPS, 2 units Tag polymerases ( promega, Madison, USA) in a fnal volume of $50 \mathrm{ul}$. The PCR was run for 40 cycles consisting of sequential denaturation $\left(95^{\circ} \mathrm{C}\right.$ for $1 \mathrm{~min}$ ) annealing $\left(57{ }^{\circ} \mathrm{C}\right.$ for $\left.1 \mathrm{~min}\right)$ and extension ( $72^{\circ} \mathrm{C}$ for $1-2 \mathrm{~min}$ ) followed by a final extension step at $72^{\circ} \mathrm{C}$ for $10 \mathrm{~min}$.

Agarose gel electrophoresis

The amplified PCR products of collagen and AT-1 gene were electrophoresed on $1.5 \%$ agarose gel with DNA size marker and were ultraviolet visualized by ethidium bromide staining and were semiquantified using densitometry (Bio Doc analyzer)

\section{Statistical analysis}

Data are presented as means \pm SD. Comparisons among groups were performed using the student $\mathrm{T}$ test and analysis of variance as required. Differences were considered significant at $\mathrm{P}<0.05$ level.

\section{RESULTS}

The results of our study show that ovariectomy resulted in a significant decrease in all parameters of myocardial hemodynamic performance when compared to controls. Such reduction was significantly improved towards normal values in the ovariectomized plus estrogen treated group. Chelerythrene in group IV partially blocked the improvement in ventricular performance induced by estrogen on all hemodynamic parameters when compared to group III $(\mathrm{P}<0.05)$. Table 1$)$ 
In our research, left ventricular axis in the ovariectomy group increased significantly when compared to control, and though left ventricular weight also increased significantly as compared to control, however, left ventricular weight over total heart weight did not reach statistical significant increase $(\mathrm{P}=0.05)$ when compared to control.

Estrogen replacement led to a significant decrease in the left axis of the heart when compared to the ovariectomy group although the left ventricular weight (lftwt)/total heart weight (THW) did not significantly change from control and ovariectomy groups.

The protein kinase $\mathrm{C}$ (PKC) inhibitor chelerythrene partially inhibited the effect of estrogen on left axis measurements. However, the ratio of lftwt /THW was not statistically different from the estrogen group, so it seems that this blocking effect of chelerythrene on the actions of estrogen is not limited to the left ventricle and extends to the rest of the heart. (Table 2)
In our study, ovariectomy significantly increased the level of expression of collagen type I, the activity of MMP- 9 as well as the expression of the AT1 receptor in left ventricular tissue when compared to controls $(\mathrm{P}<0.05)$.

Estrogen replacement for four weeks in ovariectomized rats reduced the increased expression of both collagen type $1 \&$ ATI and the elevated level of MMP-9 in left ventricular samples when compared to the ovariectomy group, though not quite to control levels.

The addition of the protein kinase $\mathrm{C}$ inhibitor chelerythrene to estrogen treatment in group IV resulted in partial block to the effect of estrogen replacement as it lead to a significant reduction in the decrease in collagen type I \& AT-I expression and MMP- 9 ventricular tissue level when compared to the estrogen group. However, such values were still significantly lower than ovariectomy group suggesting that chelerythrene did not totally block the effects of estrogen on such parameters. [(Table $3)$ and figs $(1,2)]$.

Table (1): Left ventricular systolic pressure (LVSP) in $\mathrm{mmHg}$, HR in beats/ min and $\mathrm{dp} / \mathrm{dt}(\mathrm{mmHg} / \mathrm{sec})$ for all groups included in the study 4 weeks after the start of experimental protocol

\begin{tabular}{|l|l|l|l|l|}
\hline Group & $\mathrm{n}$ & LVSP & HR & $\mathrm{dp} / \mathrm{dt}$ \\
\hline I. Sham & 6 & $102 \pm 10.2$ & $193 \pm 16.8$ & $5450 \pm 530$ \\
\hline II. Ovx & 16 & $62.4 \pm 13.3^{*}$ & $106.6 \pm 23.8^{*}$ & $2763 \pm 642^{*}$ \\
\hline III.Ovx+est. & 18 & $104.75 \pm 12.2 * *$ & $167.2 \pm 20.05 * *$ & $7575 \pm 221^{* *}$ \\
\hline IV. Ovx + est + chl & 10 & $78 \pm 9.3 \$$ & $120 \pm 18.6 \$$ & $3455 \pm 440 \$$ \\
\hline
\end{tabular}

Results are mean \pm SD.

Sham $=$ Sham operated, Ovx $=$ ovariectomy, Ovx + est $=$ ovariectomy + estrogen

$\mathrm{Ov}+\mathrm{est}+\mathrm{chl}=$ ovariectomy + estrogen + chelerythrene.

* significant change when compared to sham group. $\mathrm{P}<0.05$

** significant change when compared to ovariectomy gp, $\mathrm{P}<0.05$

$\$$ significant change when compared to ovarariectomy+estrogen group. $\mathrm{P}<0.05$ 
Table (2): Left axis diameter in $\mathrm{mm}$, left ventricular weight in $\mathrm{mg}$, total heart weight in $\mathrm{mg}$ and left ventricular weight on total weight for all groups included in the study 4 weeks after the start of experimental protocol

\begin{tabular}{|l|l|l|l|l|l|}
\hline \multicolumn{1}{|c|}{ Group } & $\mathrm{N}$ & \multicolumn{1}{|c|}{ Left axis $(\mathrm{mm})$} & $\begin{array}{c}\text { Lftwt } \\
(\mathrm{mg})\end{array}$ & $\begin{array}{c}\text { THW } \\
(\mathrm{mg})\end{array}$ & Lftwt/THW \\
\hline I.Sham & 6 & $1.8 \pm 0.0816$ & $0.45 \pm 0.1$ & $0.64 \pm 0.11$ & $0.7 \pm 0.06$ \\
\hline II.ovx & 16 & $2.4778^{*} \pm 0.278$ & $0.58 \pm 0.09^{*}$ & $0.77 \pm 0.1^{*}$ & $0.751 \pm 0.04$ \\
& & & & & \\
\hline III.ovx+est. & 18 & $2.0250^{* *} \pm 0.0856$ & $0.52 \pm 0.07 * *$ & $0.72 \pm 0.12$ & $0.725 \pm 0.06$ \\
\hline IV.ovx+est+chl & 10 & $2.1100 \pm 0.152 \$$ & $0.48 \pm 0.09$ & $0.69 \pm 0.06$ & $0.695 \pm 0.12$ \\
\hline
\end{tabular}

Results are mean $\pm \mathrm{SD}$.

Sham $=$ Sham operated, $\mathrm{Ovx}=$ ovariectomy, Ovx + est $=$ ovariectomy + estrogen

$\mathrm{Ov}+\mathrm{est}+\mathrm{chl}=$ ovariectomy + estrogen + chelerythrene, $\mathrm{Lftwt}=$ left ventricular weight, $\mathrm{THW}=$ total heart weight, lftwt/THW= left ventricular weight/total heart weight. .

* Significant change compared to sham. $\mathrm{P}<0.05$

** Significant change compared to ovariectomy. $\mathrm{P}<0.05$

$\$$ Significant change compared to ovariectomy+estrogen. $\mathrm{P}<0.05$

Table (3): MMP-9 level in ng/ml, collagen type I level in $\mathrm{ug} / \mathrm{ml}$, and AT1 expression level in $\mathrm{pg} / \mathrm{mg}$ tissue protein as measured in left ventricular tissue taken from all animals involved in the study 4 weeks after the start of the experimental protocol.

\begin{tabular}{|l|l|l|l|l|}
\hline \multicolumn{1}{|c|}{ Groups } & \multicolumn{1}{c|}{$\mathrm{n}$} & \multicolumn{1}{c|}{ MMP-9 } & \multicolumn{1}{c|}{ Collagen type I } & \multicolumn{1}{c|}{ AT1 } \\
\hline I. Sham & 6 & $631.42 \pm 33.3$ & $133.97 \pm 19.1$ & $55.775 \pm 8.15$ \\
\hline II.Ovx & 16 & $1076.8 \pm 226^{*}$ & $470.09 \pm 155^{*}$ & $101.79 \pm 21.3^{*}$ \\
\hline III.Ovx+estrogen & 18 & $752.63 \pm 96.1 * *$ & $266.89 \pm 94.9^{* *}$ & $70.217 \pm 18.1^{* *}$ \\
\hline IV.Ovx+est+chl & 10 & $943.32 \pm 45.9 \$$ & $344.23 \pm 42.4 \$$ & $88.660 \pm 7.43 \$$ \\
\hline
\end{tabular}

Results are mean \pm SD.

Sham $=$ Sham operated, $\mathrm{Ovx}=$ ovariectomy, $\mathrm{OVx}+\mathrm{est}=$ ovariectomy + estrogen

$\mathrm{Ovx}+\mathrm{est}+\mathrm{chl}=$ ovariectomy + estrogen + chelerythrene, AT1= Angiotensin II type I receptor, MMP9=Metalloproteinase 9. .

* significant change when compared to sham group. $\mathrm{P}<0.05$

** significant change when compared to ovariectomy gp, $\mathrm{P}<0.05$

$\$$ significant change when compared to ovarariectomy+estrogen group. $\mathrm{P}<0.05$ 
Figure (1) showing an agarose gel electrophoresis of gene expression of AT-1 by RT-PCR:

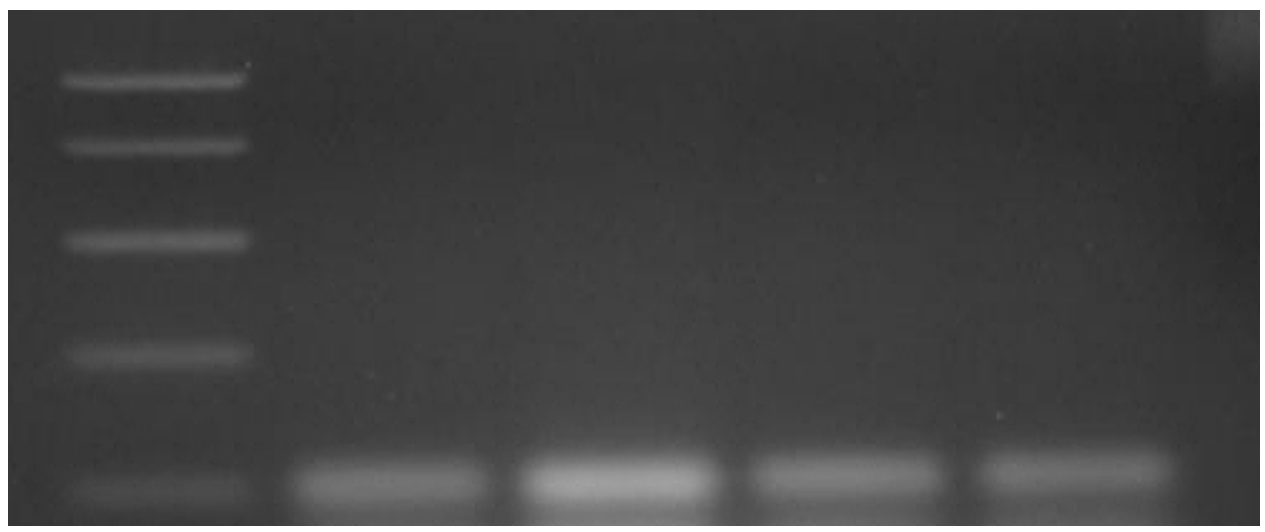

$\begin{array}{lllll}M & 1 & 2 & 3 & 4\end{array}$

Lane M: PCR marker

Lane 1: PCR product of AT-1 in control group

Lane2: PCR product of AT-1 in group 2

Lane 3: PCR product of AT-1 in group 3

Lane 4: PCR product of AT-1 in group 4

Figure (2) shows an agarose gel electrophoresis of gene expression of collagen type I by RT-PCR:

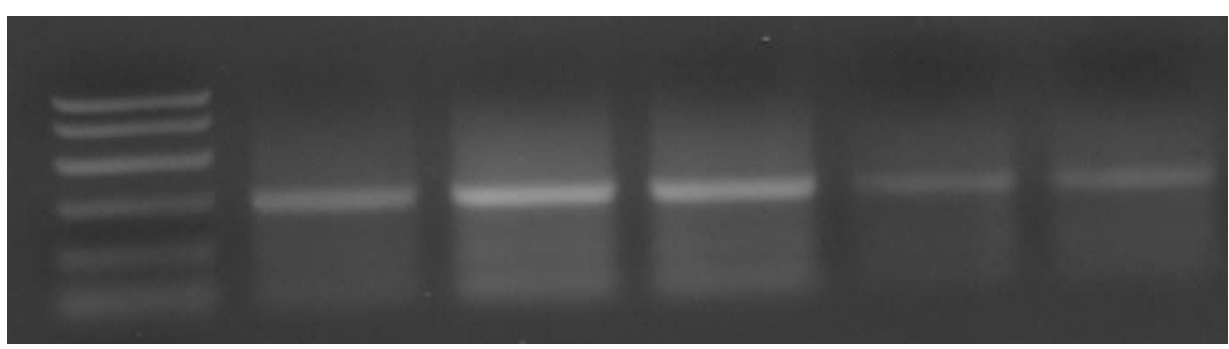

$\begin{array}{llllll}M & 1 & 2 & 3 & 4 & 5\end{array}$

Lane M: PCR marker

Lane 1: PCR product of collagen-1 in control group

Lane2\&3: PCR product of collagen-1in group 2

Lane 4: PCR product of collagen-1in group 3

Lane 5: PCR product of collagen-1in group 4 


\section{DISCUSSION}

In our present study, we have attempted to examine the possible role and mechanism of action of estrogen in the process of regulation of cardiac remodeling and left ventricular function in female rats. Such an aim was achieved through evaluation of the effects of ovariectomy alone, in combination with estrogen treatment and in combination with estrogen and the protein kinase $\mathrm{C}$ inhibitor chelerythrene treatment on cardiac performance parameters and ventricular tissue levels of MMP- 9 as well as on expression of collagen type I \& AT1 in the different studied groups.

In our study, ovariectomized rats receiving no form of treatment showed a significant decrease in all hemodynamic cardiac performance parameters when compared to controls 4 weeks after sham operation was performed.

Our results can be partly explained by previous research findings that estrogen increases cardiac output through an increase in stroke volume and heart rate but without any direct effect on myocardial contractility ${ }^{(\mathbf{1 2})}$. It is conceivable that the lack of estrogen in the ovariectomized group led to a significant reduction in cardiac output thus reducing the developed pressure by the left ventricle.

Scheuer et al. ${ }^{(13)}$, however, suggested that in the isolated working heart, contractile performance was diminished in the ovariectomized rat, and was shown to be due in part to an alteration in the expression of different types of myosin heavy chain kinases with an increase in $\mathrm{V}_{3}$ myosin heavy chain expression, and a reciprocal decrease in the $\mathrm{V}_{1}$ isoform expression which can lead to a reduced contractile perfermonce of the heart.

Our results are in contrast to the results of Mercier et al. ${ }^{\text {(14) }}$ who found that ovariectomized rats had higher left ventricular systolic pressures and mean arterial pressures (MAP) at 3 and 6 weeks post- ovariectomy. However, their measurements were conducted in vivo and not in isolated hearts and they suggested that high levels of endothelin-1 secreted abluminally, and acting as a local autocrine/paracrine factor on endothelin A receptor were responsible for the increased MAP and systolic ventricular pressures as well as $\mathrm{dp} / \mathrm{dt}$ observed in their experiments.

Estrogen has been postulated also to induce down-regulation of the protein thymosin $\beta 10$, which is an actin monomer-sequestering $\operatorname{protein}^{(\mathbf{1 5})}$. This effect might play an important role in actin dynamics and in the maintenance of contractility in normal female animals which could also explain our finding of reduced left ventricular systolic pressure in ovariectomized animals.

In our research, left ventricular axis and left ventricular weight in the ovariectomized group increased significantly when compared to the control sham operated group. However, the increase in left ventricle weight was matched to a similar increase in total heart weight so that the ratio of left ventricle/total heart weight was not significantly increased above sham operated group. Such 
results suggest a form of hypertrophy that affects all chambers of the heart associated with reduced left ventricular performance as was shown from deterioration of left ventricular systolic pressures in the ovariectomized group.

Myocardial

hypertrophy frequently develops in older humans. Women have a lower overall incidence of left ventricular hypertrophy than men, but left ventricular hypertrophy in postmenopausal women exceeds the incidence in age-matched males ${ }^{(16)}$. Such findings suggest that possibly reduction of ovarian hormones can lead to increased incidence of cardiac hypertrophy.

The mechanism through which estrogen can control myocardial hypertrophy has received much attention. Much data support a central role for the protein phosphatase, calcineurin, in the development of cardiac hypertrophy ${ }^{(17)}$. Hypertrophic agents such as Angiotensin II, Endothelin-1, and Phenylephrine upregulate the activity of this enzyme in a calcium-dependent fashion. When calcineurin is induced, it promotes the formation and translocation of nuclear factors that up-regulate hypertrophic genes $^{(\mathbf{1 8 )}}$. Pedram et al. ${ }^{(\mathbf{1 6})}$ suggest that estrogen strongly inhibits the activity of calcineurin so that in its absence; the cardiomyocyte hypertrophic response to Ang II or ET-1 is less controlled leading to hypertrophy of the heart as seen in old menopausal women.

On the other hand, estrogen supplementation lead to a significant reduction in left ventricular weight as compared to the ovariectomized group. Estrogen also led to a decrease in the total weight of the heart (though not reaching statisitical significance) when compared to ovariectomized group .

Cardiomyocyte hypertrophy is characterized by an increase in cellular volume with an enhanced sarcomeric organization of individual myocytes $^{(\mathbf{1 9 )}}$. The molecular response of the hypertrophied left ventricular myocytes involves the re-induction of genes transiently expressed during embryogenesis and is initiated by complex cascades of cytoplasmic signalling events ${ }^{(20)}$. Babiker et al. ${ }^{(21)}$ suggest that estrogen-mediated antagonism of hypertrophy is developed through a guanylyl cyclase A (GC-A) receptor signalling in cultured cardiomyocytes as well as a direct stimulation of atrial natriuretic peptide (ANP) expression. ANP stimulates cGMP to defend against cardiomyocyte hypertrophy and it seems that ANP and brain natriurietic peptide (BNP) production and secretion are stimulated by estrogen.

In our studies, treatment of ovariectomized rats with both the chelerythrene and estrogen lead to a partial inhibition of the effect of estrogen on the left ventricle and the rest of the heart suggesting that possibly protein kinase $\mathrm{C}$ is partially involved in mediating estrogen actions.

Estrogen modulation of cardiac function requires the primary binding of estrogen to its specific receptors in cardiac tissue. Jager et al. ${ }^{(22)}$ suggest that functional estrogen receptors of both alpha and beta type are present in the myocardium and regulate the expression of relevant target genes 
such as connexin 43 which is one of the major contractile proteins in the heart. The binding of the steroid hormone estradiol (E2) to nuclearlocalized receptors modulates the transcription of genes that initiate the functions attributed to the sex steroid $^{(23)}$. However, it has been recently suggested that E2 also binds to a smaller pool of plasma membrane receptors leading ${ }^{(24)}$ to signalling through $G$ proteins and stimulating the activation of several kinases ${ }^{(\mathbf{2 5})}$.

The ability of estrogen to work through stimulation of both protein kinases PKA and PKC has previously been demonstrated ${ }^{(\mathbf{2 6})}$ in the regulation of $\mathrm{Cl}^{-}$secretion by the female rat distal colonic epithelium. $17 \mathrm{~B}$. Estradiol inhibited colonic $\mathrm{Cl}^{-}$ secretion, which involved intracellular $\mathrm{Ca}^{2+}$ and PKC.

Protein kinase $\mathrm{C}$ involvement in estrogen signalling has also been proved in neural cells. Estrogen receptor was found to activate protein kinase $\mathrm{C}$ and protein kinase $\mathrm{A}$ and uncouple opioidergic and gabanergic receptors from their effector signaling molecules ${ }^{(27)}$.

Based on these observations, it might be possible that protein kinase $\mathrm{C}$ is also involved in estrogen signalling in the myocardium which can explain our findings that protein kinase $\mathrm{C}$ inhibition partially blocked the protective effect of estrogen against cardiac hypertrophy.

In our study, ovariectomy significantly increased the expression of collagen type I when compared to Group I while estrogen supplementation in ovariectomized rats significantly reduced collagen type I expression when compared to ovariectomized rats (Group II). Supplementation of ovariectomized rats with both estrogen and chelerythrene partially reduced the significant reduction of collagen expression that resulted from estrogen supplementation alone.

Although the heart's primary function as a pump depends mainly on the cardiomyocyte, its structural and functional integrity depends largely on the non-myocyte fibroblast. The fibroblast is, in fact, the predominant cell type in heart and plays a major role in the deposition of the extracellular matrix, of which collagen is a major component ${ }^{(28)}$. Cardiac fibroblasts are known to synthesize fibronectins, vitronectin, collagen types I, III, and V, and collagenases, among many other extracellular matrix and extracellular matrix-related proteins $^{(29)}$.

Collagen type $\mathrm{I}$ is the major collagenous product of cardiac fibroblasts, representing $80 \%$ of total newly synthesized collagen, which is secreted into the culture medium as procollagens. About $20 \%$ of the total collagen synthesized is collagen type III, and a small proportion is collagen type $\mathrm{V} \quad(<5 \%) \quad(28)$. Excessive deposition of cardiac extracellular matrix (fibrosis) has been associated with the pathological mechanical overload of heart ${ }^{(30)}$. Cardiac fibrosis is associated with the three most prevalent chronic cardiovascular diseases, namely hypertension ${ }^{(31)}$, heart failure ${ }^{(32)}$, and myocardial infarction $^{(33)}$.

The mechanism for the increase of myocardial collagen fiber content is the loss of myocytes, which are postmitotic cells and are replaced as 
they $\operatorname{die}^{(34)}$. The loss of myocytes could explain the accumulation of collagen in the walls of the ventricles. Another mechanism for collagen accumulation may be inhibition of collagen degradation $^{(35)}$, but the factor responsible for the increase of myocardial collagen fibre content is still a matter of research. Increased collagen expression by ovariectomy has also been suggested in other tissues. Ye et al. ${ }^{(36)}$ found that in adipocytes, some components of ECM were up-regulated by ovariectomy such as procollagen type I and, fibronectin 1 .

Otsuki, et al. ${ }^{(37)}$ suggested an interpretation for the increased collagen type I expression in ovariectomized animals. They suggested that in the cardiovascular system, estrogen downregulates several genes that encode for extracellular matrix (ECM) proteins such as $\alpha_{1}$, type I procollagen, $\alpha_{1}$, type III procollagen \& type XV procollagen. In ovariecotmized animals, it seems that cardiac fibroblasts may contribute to pathological structural changes in the heart by proliferating, depositing ECM proteins, and replacing tissue rich in myocytes with fibrotic tissue ${ }^{(38)}$. Another possible mechanism for the effect of estrogen on collagen expression has been suggested by Dubey et al. ${ }^{(39)}$ who reported that estradiol inhibits cardiac fibroblast growth via an estrogen receptorindependent pathway that involves local metabolism of estradiol to methoxyestradiols .

Our results with the protein kinase $\mathrm{C}$ inhibitor chelerythrene suggest the possibility that protein kinase $\mathrm{C}$ is involved in the regulation of the effect of estrogen on cardiac fibroblasts.

Protein kinase $\mathrm{C}(\mathrm{PKC})$ is a family of at least 10 serine/threonine kinases. As major mediators of signal transduction pathways, PKCs have been shown to regulate a diverse set of biological functions, such as cell growth, differentiation, apoptosis, transformation,

and tumorgenicity ${ }^{(\mathbf{4 0}, 41)}$.

$\mathrm{PKC}-\delta$ and PKC- $\varepsilon$ mediate quite contrasting physiological effects and give an interesting insight into the large possibilities offered by this family of kinases. Overexpressed PKC- $\varepsilon$ stimulates growth and is oncogenic in mouse, rat, and human fibroblasts as well as in rat colon epithelial cells ${ }^{(41)}$. In contrast, $\mathrm{PKC}-\delta$ inhibits cell growth in fibroblasts ${ }^{(\mathbf{4 2})}$ and induces differentiation in promyelocytic cells $^{(\mathbf{4 0})}$. PKC- $\delta$, when over-expressed in vascular smooth muscle cells, induces apoptosis while PKC- $\varepsilon$ does not ${ }^{(43)}$. In salivary gland acinar cells, PKC- $\delta$ is also essential for induced apoptosis ${ }^{(44)}$.

As inhibition of protein kinase $\mathrm{C}$ led to an increase in the expression of collagen type I in cardiac tissue, our results seem to suggest that estrogen mediates part of its action on fibroblasts through activation of a special type of protein kinase that inhibits collagen deposition in the heart. .

In our study, ovariectomy significantly increased the ventricular level of metalloproteinase 9 enzyme when compared to controls while estrogen supplementation in ovariectomized rats significantly reduced MMP 9 level when compared 
to ovariectomized animals not receiving estrogen. Supplementation of ovariectomized rats with both estrogen and chelerytherene led to partial inhibition of reduction of MMP 9 level in ventricular tissue samples when compared to group III.

MMPs are an ever-expanding family of endopeptidases with common functional domains and ability to degrade ECM components. MMP actions have been implicated in both physiological and pathological tissue reshaping, including organ development, wound healing, inflammation, and cancer ${ }^{(45)}$. MMP activity is regulated at multiple levels: gene transcription and synthesis of inactive zymogens and posttranslational activation of zymogens. Enzymatic activation requires removal of their prodomain, which can occur through degradation by other proteases, such as plasmin, or cell-associated membrane-type MMPs (MT-MMPs). Once activated, MMPs participate in a broad spectrum of physiological and pathological processes including, but not limited to, degradation of ECM components. Other important non matrix MMP substrates include molecules whose biological activity is regulated by

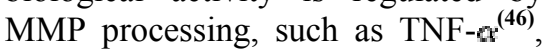
growth factors and their receptors ${ }^{(47)}$ plasminogen and its activators, and endothelin $^{(48)}$.

MMPs have been implicated in induction of dilation in blood vessel walls. Pasterkamp et al. ${ }^{(49)}$ observed more MMP-2 and MMP-9 in plaques of expansively remodelled arterial segments compared with constrictively remodelled segments of human coronary arteries.
Experimental overexpression of MMP-9 in rat smooth muscle cells also led to enlargement of the circumference of such arteries ${ }^{(\mathbf{5 0})}$. On the other hand, non-selective MMP inhibition was found to diminish expansive arterial remodeling of rat arterio-venous fistulae ${ }^{(51)}$. Aneurysmal arterial dilation may represent an extreme form of outward remodeling. Increased MMP-2 and MMP-9 expression were detected in human abdominal aortic aneurysms ${ }^{(\mathbf{5 2})}$.

Based on the above observations, it is possible to suggest that increased MMP-9 activity in the ovariectomized rats is an essential mediator in the production of ventricular dilatation especially, it was associated with increased left ventricular axis in our results.

On the other hand, the mechanism through which estrogen reduces metalloproteinase expression is complex. Previous studies demonstrated that cardiac mast cell degranulation mediates MMP activation and extra-cellular matrix degradation $^{(\mathbf{5 3})}$. Estrogen seems to prevent the mast cell-mediated MMP activation and extracellular matrix degradation previously demonstrated in male rats ${ }^{(\mathbf{5 4})}$. Harnish et al. suggest (55) that non-cardiac mast cell proteases were downregulated by estrogen while Chancey et al. ${ }^{(56)}$ suggest that increased degradation of extracellular matrix proteins and ventricular dilatation in the ovariectomized female hearts is consistent with their observed changes in MMP-2 activity.

Other researchers also found a significant increase in mast cellmediated MMP-2 activation in hearts 
from ovariectomized rats $^{(57)}$. However, the biology of matrix remodeling is likely to be much more complex than the simple presence or absence of MMP as degradation of matrix is also controlled by other glycoproteins; the tissue inhibitors of matrix metalloproteinases (TIMPs). These molecules are capable also of regulation of the activation of MMPs by binding to and preventing these enzymes from degrading the collagen matrix of the heart. However, the exact role of TIMPs is far from clear. It seems that under certain conditions, they actually stabilize or localize MMPs which in turn facilitates their activation $^{(58)}$.

In our study, ovariectomy significantly increased the level of expression of AT1 receptors in ventricular samples when compared to levels obtained in controls while estrogen supplementation in ovariectomized rats (group III) significantly reduced AT1 receptor expression when compared to group II. Supplementation of ovariectomized rats with both estrogen and chelerythrene (group IV) led to a significant reduction in the decrease of the levels of AT1 expression caused by estrogen alone suggesting the involvement of PKC in the mediation of estrogen action on AT1 expression in the heart.

Our results agree with Dean et al. who also found that ovariectomy alone leads to increased both right and left ventricular AT1 receptors as well as ACE activity and such events were prevented by treatment with regular estrogen $^{(\mathbf{8})}$. Nickenig et al. ${ }^{(\mathbf{5 9})}$ also found that ovariectomy alone increases AT1 receptor mRNA abundance, AT1 receptor binding density and ACE activity in the aorta and such effects were prevented by estrogen treatment. Similar results were found in adrenal cortex and subfornical region in the brain $^{(\mathbf{6 0}, \mathbf{6 1})}$.

The renin angiotensin system is a major endocrine, paracrine and autocrine regulator within the cardiovascular system. Ang II is the main effector peptide of the reninangiotensin system that plays an important role in several cardiovascular diseases associated with vascular smooth muscle cell (VSMC) growth and inflammation, including hypertension, atherosclerosis, restenosis after balloon injury, and myocardial infarction $^{(62)}$. Ang II exerts its biological effects through the stimulation of specific receptors located on the cell surface. $\mathrm{AT}_{1}$ mediates many important cardiovascular responses, such as vasoconstriction, vascular and cardiac remodeling, and cell survival/death ${ }^{(63)}$ and evokes several intracellular signals such as calcium mobilization and activation of protein kinases, including protein kinase $\mathrm{C}$ (PKC) and mitogen-activated protein (MAP) cascade ${ }^{(64)} . \mathrm{AT}_{2}$ is involved in some Ang II actions, including apoptosis and inflammatory cell recruitment, and elicits different second messengers, such as MAP phosphatase activation and kinase inhibition $^{(65)}$.

It has been previously suggested that the estrogen-estrogen receptor complex can regulate gene transcription rates of AT1 receptors. Although the gene promoter regions of the AT1 Receptor gene do not 
contain a consensus or near consensus estrogen response element, they contain near-consensus activating protein 1 sites, which could be potentially regulated by estrogenestrogen receptor complex. Regulation of mRNA transcript stability and translation into protein has also been proposed as a possible mechanism of estrogen action on AT1 expression ${ }^{(66)}$. Estrogen treatment increased the association of cytosolic RNA binding proteins to the leader sequence of AT1 $\mathrm{R}$ mRNA. These binding proteins interfere with ribosomal scanning and may inhibit AT1 R translation efficiency $^{(60)}$.

Our results with chelerythrene suggest that estrogen partly regulates AT1 expression through a mechanism that partly involves protein kinase $\mathrm{C}$.

Holtzmeister et al (67) previously suggested the involvement of protein kinase $\mathrm{C}$ activation in regulation of AT1 receptor expression in VSMC. Protein kinase $\mathrm{C}$ seems to induce phosphorylation of several mitogenactivating protein kinases (MAPK) resulting in activation of activator protein 1 (AP-1) which can then bind to and modulate the activity of AT1promoter fragment.

Protein kinase $\mathrm{C}$ has also been documented to regulate several other receptors involved in myocardial function such as the $\mathrm{B}$ adrenergic receptors $^{(\mathbf{6 8})}$.

In conclusion, our study suggests that estrogen can maintain myocardial contractile performance and play a cardiac protective role in female rats through regulating certain key elements involved in the process of ventricular remodeling, including collagen type I, MMP-9 and angiotenisn II type I receptor. Such effects might be partly mediated through the activation of protein kinase $\mathrm{C}$ enzyme. More research into the pathways mediating estrogen action is required to solve the debate surrounding its protective effect on the cardiovascular system in clinical trials.

\section{REFERENCES}

1. Swynghedauw B. Molecular mechanisms of myocardial remodeling. Physiol Rev 79: 215262, 1999.

2. Siwik D, Colucci W. Regulation of matrix metalloproteinases by cytokines and reactive oxygen/nitrogen species in the myocardium. Heart failure Review 9: 43-51, 2004.

3. Díez J. Profibrotic effects of angiotensin ii in the heart.a matter of mediators. Hypertension. 43:1164-1170, 2004.

4. Sundström J, Evans JC, Benjamin EJ, Levy D et al. Relations of plasma matrix metalloproteinase-9 to clinical cardiovascular risk factors and echocardiographic left ventricular measures .The Framingham Heart Study. Circulation 109:28502856, 2004.

5. Eaker ED, Chesebro JH, Sacks FM, Wenger NK, Whisnant JP, and Winston M. Cardiovascular disease in women. Circulation 88: 1999-2009, 1993.

6. Janicki JS, Brower GL, Gardner JD, et al. The dynamic interaction between matrix metalloproteinase activity and 
adverse myocardial remodeling. Heart Fail Rev. 9: 33-42, 2004.

7. Writing group for women's health initiative investigators. Risks and benefits of oestrogen plus progestins in healthy postmenopausal women: Prinicipal results from the women's health initiative randomized controlled trial. JAMA 288:321-333, 2002.

8. Dean s, Tan J, O'Brien $E$ and Leenen F. 17 B Estradiol downregulates tissue angiotensinconverting enzyme and ANG II type 1 receptor in female rats. Am. J Physiol Regul Integr Comp Physiolo 288: R 759-R 766, 2005.

9. Waynforth HB. Experimental and surgical techniques in the rat. New York, NY: academic, 1980.

10. Sand E, Saeda L. Quantification of bcl-2 protein in bladder cancer tissue by enzyme immunoassay: comparison with western blot and immnuohistochemistry. Clin chem. 44 (7): 1423-1429, 1999.

11. Chomkezynnski $P$ and Sacchi N. Single step method of RNA isolation by acid guanidium thiocyanate phenol chloroform method. Analytical Biochemistry 162 : 156-160, 1987.

12. Beyer ME, Yu G, Hanke $H$ and Hoffmeister HM. Acute genderspecific hemodynamic and inotropic effects of $17 ß$-estradiol on rats. Hypertension 38:10031010, 2001.

13. Scheuer J., Malhotra A., Schaible TF. and Capasso J. Effects of gonadectomy and hormonal replacement on rat hearts. Circ. Res. 61: 12-19,1987.
14. Mercier I, Pham-Dang $M$, Clement R, Gosselin $\mathrm{H}$, Colombo F, Rouleau $J$ and Calderone A. Elevated mean arterial pressure in the ovariectomized rat was normalized by ETA receptor antagonist therapy: absence of cardiac hypertrophy and fibrosis. British Journal of Pharmacology 136: 685-692, 2002.

15. Yu FX, Lin SC, MorrisonBogorad M, Atkinson MA, Yin HL. Thymosin $B 10$ and thymosin B 4 are both actin monomer sequestering proteins. J Biol Chem 268:502-509, 1993.

16. Pedram A, Razandi M, Aitkenhead M, and Levin E. Estrogen inhibits cardiomyocyte hypertrophy in vitro; Antagonism of calcineurin related hypertrophy through induction of MCIP1. J. Biol. Chem. 280(28): 2633926348, 2005.

17. Vega, R.B., Yang, J, Rothermel B.A., Bassel-Duby R., and Williams R.S. Multiple domains of MCIP1 contribute to inhibition of calcineurin activity. J. Biol. Chem. 277:30401-30407, 2002

18. Wilkins, B. J., De Windt, L. J., Bueno, O. F., Braz, J. C., Glascock, B. J., Kimball, T. F., and Molkentin, J. D. Targeted disruption of NFATc3 but not NFATc4 reveals an intrinisic defect in calcineurin mediated cardiac hypertrophic growth. Mol. Cell. Biol. 22: 7603-7613, 2002.

19. Hunter JJ and Chien KR. Signaling pathways for cardiac hypertrophy and failure. N Engl J Med. 341: 1276-1283, 1999. 
20. Molkentin J, Dorn IG. Cytoplasmic signalling pathways that regulate cardiac hypertrophy. Annu Rev Physiol. 63: 391-426, 2001.

21. Babiker FA, MS; De Windt,LJ; Van Eickels M, Thijssen V,; Ronald J.P. Bronsaer MS; Grohé C, van Bilsen $M$, Doevendans PA. 17ß-Estradiol antagonizes cardiomyocyte hypertrophy by autocrine/paracrine stimulation of a guanylyl cyclase a receptorcyclic guanosine monophosphatedependent protein kinase pathway. Circulation 109:269276, 2004.

22. De Jager T, Pelzer T, MüllerBotz S, Imam A, Muck J, and Neyses L. Mechanisms of estrogen receptor action in the myocardium: rapid gene activation via the ERK1/2 pathway and serum response elements. J. Biol. Chem 276(30): 27873-27880, 2001.

23. White R, Parker MG. Molecular mechanisms of steroid hormone action. Endocr Relat Can 5:114,1998

24. Levin ER. Cell localization, physiology and nongenomic actions of estrogen receptors. J Appl Physiol 91:1860-1867, 2001.

25. Kelly M, Levin ER. Rapid actions of plasma membrane estrogen receptors. Trends Endocrinol Metab 12:152-156, 2001.

26. Doolan CM, Condliffe SB, and Harvey BJ. Rapid non-genomic activation of cytosolic cyclic AMP-dependent protein kinase activity and $\left[\mathrm{Ca}^{2+}\right]_{\mathrm{i}}$ by $17^{\mathrm{B}}$. oestradiol in female rat distal colon. $\mathrm{Br} \mathrm{J}$ Pharmacol 129: 1375-1386, 2000.

27. Barbaccia ML, Serra M, Purdy RH, and Biggio G. Stress and neuroactive steroids. Int Rev Neurobiol 46: 243-272, 2001.

28. Jugdutt BI. Modification of left ventricular remodeling after myocardial infarction. In: The Failing Heart, edited by Dhalla NS, Beamish RE, and Nagano $M$. New York: Raven,.p 231-45, 1995.

29. Tyagi SC, Lewis $K$, Pikes $D$, Marcello A, Mujumdar VS, Smiley LM, and Moore CK. Stretch-induced membrane type matrix metalloproteinase and tissue plasminogen activator in cardiac fibroblast cells. J Cell Physiol 176: 374-382, 1998.

30. Weber KT, Brilla CG, and Campbell SE. Regulatory mechanisms of myocardial hypertrophy and fibrosis: results of in vivo studies. Rev Cardiol 81: 266-273, 1992.

31. Weber KT, Janicki JS, Shroff SG, Pick R, Chen RM, and Bashey RI. Collagen remodeling of the pressure-overloaded, hypertrophied non human primate myocardium. Circ Res 62: 757$765,1988$.

32. Weber KT, Anversa P, Armstrong PW, Brilla CG, Burnett JC Jr, Cruickshank JM, Devereux RB, Giles TD, Korsgaard N, Leier CV, et al. Remodeling and reparation of the cardiovascular system. J Am Coll Cardiol 20: 3-16, 1992. 
33. Anversa P, Olivetti G, and Capasso JM. Cellular basis of ventricular remodeling after myocardial infarction. Am J Cardiol 68: 7D-16D,1991.

34. Olivetti G, Melissari M, Capasso JM, and Anversa $P$. Cardiomyopathy of the aging human heart. Myocyte loss and reactive cellular hypertrophy. Circ Res 68:1560-1568, 1991

35. Robert V, Besse S, Sabri A, Silvestre JS, Assayag P, Nguyen VT, Swynghedauw $B$, and Delcayre C. Differential regulation of matrix metalloproteinases associated with aging and hypertension in the rat heart. Lab Invest 76: 729738, 1997.

36. Ye $P$, Yoshioka $M$, Gan $L$ and St-Amand J. Regulation of Global Gene Expression by Ovariectomy and Estrogen in Female Adipose Tissue. Obesity Research 13:1024-1030, 2005.

37. Otsuki M, Gao H, DahlmanWright K, Ohlsson C, Eguchi $N$, Urade $Y$ and Gustafsson JA. Specific Regulation of Lipocalin-Type Prostaglandin D Synthase in Mouse Heart by Estrogen Receptor $\beta$. Molecular Endocrinology 17 (9): 18441855, 2003.

38. Dubey RK, Gillespie DG, Mi Z, Jackson EK. Exogenous and endogenous adenosine inhibits fetal calf serum-induced growth of rat cardiac fibroblasts: role of A2B receptors. Circulation 96:2656-2666, 1997.

39. Dubey RK, Gillespie DG, Zacharia LC, Rosselli M, Imthurn B, Jackson EK.
Methoxyestradiols mediate the antimitogenic effects of locally applied estradiol on cardiac fibroblast growth. Hypertension 39:412-417,2002.

40. Mischak H, Pierce JH, Goodnight J, Kazanietz MG, Blumberg PM, Mushinski JF. Phorbol ester-induced myeloid differentiation is mediated by protein kinase $\mathrm{C}$ - alpha and delta and not by protein kinase C-ßII. J Biol Chem 268:20110-5,1993.

41. Perletti GP, Folini M, Lin H-C, Mischak H, Piccinini F, Tashjian AH Jr. Overexpression of protein kinase $\mathrm{C}(\varepsilon)$ is oncogenic in rat colonic epithelial cells. Oncogene 12:847-54,1996.

42. Watanabe T, Ono Y, Taniyama Y, et al. Cell division arrest induced by phorbol ester in $\mathrm{CHO}$ cells overexpressing protein kinase C-delta subspecies. Proc Natl Acad Sci USA 89:1015963,1992.

43. Goerke A, Sakai N, Gutjahr E, et al. Induction of apoptosis by protein kinase $\mathrm{C}$ delta is independent of its kinase activity. J Biol Chem 277:32054-62, 2002.

44. Reyland ME, Anderson SM, Matassa AA, Barzen KA, Quisell DO. Protein kinase C delta is essential for etoposideinduced apoptosis in salivary gland acinar cells. J Biol Chem 274:19115-23,1999.

45. Birkedal-Hansen H. Proteolytic remodeling of extracellular matrix. Curr Opin Cell Biol. 7: 728-735, 1995.

46. Gearing AJ, Beckett P, Christodoulou M, Churchill M, 
Clements J, Davidson AH, Drummond AH, Galloway WA, Gilbert R, Gordon JL. Processing of tumour necrosis factor- $\alpha$ precursor by metalloproteinases. Nature. 370: 555-557, 1994.

47. Levi E, Fridman R, Miao HQ, Ma YS, Yayon A, Vlodavsky I. Matrix metalloproteinase 2 releases active soluble ectodomain of fibroblast growth factor receptor 1. Proc Natl Acad Sci U S A. 93: 7069-7074, 1996.

48. Ugwu F, Van Hoef B, Bini A, Collen D, Lijnen HR. Proteolytic cleavage of urokinasetype plasminogen activator by stromelysin-1 (MMP-3). Biochemistry. 37: 7231-7236, 1998.

49. Pasterkamp G, Schoneveld AH, Hijnen DJ, de Kleijn DP, Teepen H, Van der Wal AC, Borst C. Atherosclerotic arterial remodeling and the localization of macrophages and matrix metalloproteases 1, 2 and 9 in the human coronary artery. Atherosclerosis 150: 245-253, 2000.

50. Mason DP, Kenagy RD, Hasenstab D, Bowen-Pope DF, Seifert RA, Coats S, Hawkins SM, Clowes AW. Matrix metalloproteinase-9

overexpression enhances vascular smooth muscle cell migration and alters remodeling in the injured rat carotid artery. Circ Res. 85: 1179-1185, 1999.

51. Abbruzzese TA, Guzman RJ, Martin RL, Yee C, Zarins CK, Dalman RL. Matrix metalloproteinase inhibition limits arterial enlargements in a rodent arteriovenous fistula model. Surgery 124:328-335, 1998.

52. Knox JB, Sukhova GK, Whittemore AD, Libby P. Evidence for altered balance between matrix metalloproteinases and their inhibitors in human aortic diseases. Circulation 95: 205212, 1997.

53. Chancey AL, Brower GL, and Janicki JS. Cardiac mast cellmediated activation of gelatinase and alteration of ventricular diastolic function. Am J Physiol Heart Circ Physiol 282: H2152H2158, 2002.

54. Murray DB, Gardner JD, Brower GL, and Janicki JS. Endothelin-1 mediates cardiac mast cell degranulation, matrix metalloproteinase activation, and myocardial remodeling in rats. Am J Physiol Heart Circ Physiol 287: H2295-H2299, 2004.

55. Harnish DC, Albert LM, Leathurby Y, Eckert AM, Ciarletta A, Kasaian $M$, and Keith JC Jr. Beneficial effects of estrogen treatment in the HLAB27 transgenic rat model of inflammatory bowel disease. Am J Physiol Gastrointest Liver Physiol 286: G118-G125, 2004.

56. Chancey AL, Gardner JD, Murray DB, Brower GL, and Janicki JS. Modulation of cardiac mast cell-mediated extracellular matrix degradation by estrogen. Am J Physiol Heart Circ Physiol 289: H316-H321, 2005. 
57. Brower GL, Gardner JD, and Janicki JS. Gender-mediated cardiac protection from adverse ventricular remodeling is abolished by ovariectomy. Mol Cell Biochem 251: 89-95, 2003.

58. Jinga DC, A. Blidaru A, Condrea I , Ardeleanu C, Dragomir C, Szegli G, Stefanescu M, Matache C. MMP-9 and MMP-2 gelatinases and TIMP-1 and TIMP-2 inhibitors in breast cancer: correlations with prognostic factors. J Cell. Mol. Med. 10 (2): 499-510, 2006.

59. Nickenig G, Baumer AT, Grohe C, Kahlert S, Strehlow k, Rozenkranz S, Stablein A, Beckers f, smits JF, Daemen MJ and Bohm M. Estrogen modulates AT1 receptor gene expression in vitro and in vivo. Circulation 97: 2197-2201,1998.

60. Wu Z, Marie C, Roesch DM, Zheng W, Verbalis JG, And Sandberg K. Estrogen regulates adrenal angiotensin AT1 receptor translation. 144:3251-3261, 2003

61. Kisley LR, Sakai RR and Fluharty SJ. Estrogen decreases hypothalamic Angiotensin II AT1 Receptor binding and mRNA I the female rat. Brain Res 844: 34-42, 1999.

62. Baker KM, Booz GW, Dostal DE. Cardiac actions of angiotensin II: role of an intracardiac renin-angiotensin system. Annu Rev Physiol. 54:227-241, 1992.
63. Timmermans PB, Wong PC, Chiu AT, Herblin WF, Benfield P, Carini DJ, Lee RJ, Wexler RW, Saye JAM, Smith RD. Angiotensin II receptors and angiotensin II receptor antagonist. Pharmacol Rev. 45:205-251, 1993.

64. Griedling KK, Ushio-Fukai M, Lassègue B, Alexander RW. Angiotensin II signalling in vascular smooth muscle cells. Hypertension. 29:366-373, 1997.

65. Matsubara

H.

Pathophysiological role of angiotensin II type 2 receptor in cardiovascular and renal diseases. Circ Res. 83:1182-1191, 1998.

66. Nickenig G, Strehlow k, Wasseman S, Baumer AT, Albory K, Sauer Hand Bohm H. Differential effects of estrogen and progesterone on "AT1" receptor gene expression in vascular smooth muscle cells. Circulation 102: 1828-1833, 2000.

67. Holzmeister J; Graf K; Warnecke C; Fleck E; RegitzZagrosek V. Protein kinase Cdependent regulation of the human AT1 promoter in vascular smooth muscle cells. Am J Physiol. 273(2 Pt 2):H655-64 1997.

68. Bouvier M, Guilbault N, Bonin H. Phorbol-ester-induced phosphorylation of the $\beta 2-$ adrenergic receptor decreases its coupling to Gs. FEBS Lett. 279: 243-248, 1991. 


\section{تقييم تاثير هرمون الاستروجين على اعادة تشكيل البطين الايسر في الفئران}

الهدف من هذة الدراسة هو بحث دور هرمون الاستروجين في اعادة تشكيل البطين الايسر في قلوب انتى الفئران.

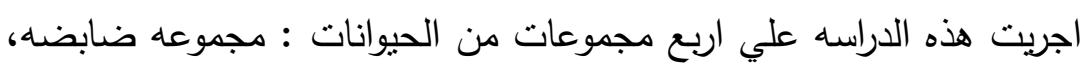
مجموعه تم استئصال الرحم بها ، مجموعه تم علاجها بهرمون الاستروجين لمدة

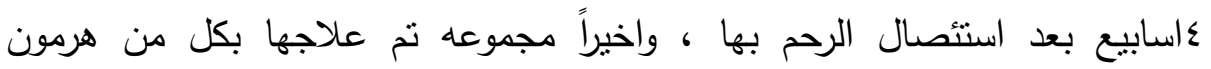
الاستروجين ومثبط بروتين كينيز Cلمدة ؛ اسابيع بعد استئصال الرحم ايضا. في نهاية مدة البحث تم قتل الفئران ثم قياس كل من: اداء البطين الايسر، محور بـن البطين الايسر ووزنه،والوزن الكلى للقلب. نم ايضاً قياس مستوي المنالو بروتينيز 9 فى انسجة البطين الايسر واظهار جين الكولاجين ا ومستقبلات الاتجيوتتسين ا ـ اظهرت نتائج هذا البحث ان استئصال الرحم قد ادى الى انخفاض الضغط في البطين الايسر ، وزيادة في محور البطين اليسر ، ووزنه ،والوزن الكلى للقلب مقارنه بالمجموعه الضابطه ـ كما ووجدت زيادة في اظهار جين الكولاجين الومستقبلات الانجيونتسين ا، وزياده فى مستوي المتالو بروتينيز 9 في عينات انسجة البطين الايسر • اوضحت النتائج ايضاً ان علاج الحيوانات التي تم استئصال الرحم بها بهرمون الاستروجين ادى الى التحسن الميكانيكى للقلب وزيادة في ضغط البطين الايسر و البـ معدل نبضات القلب ومعدل الضغط الى المستوى الطبيعى ـ كما ادى" الى انخفاض كل من تضخم واتساع البطين الايسر بدلالة انخفاض محور البطين الايسر ووزنه

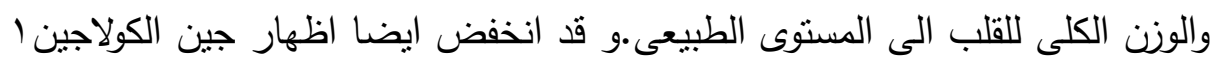
ومستقبلات الانجيوتتسين ا ، ومستوي المتالو بروتينيز 9 ـ كما وجد ان علاج الحيوانات بهرمون الاستروجين ومثبط بروتين كينيز C لمدة ؛ اسابيع نتج عنه اقفال جزئى للحمايه الناتجه عن العلاج بهرمون الاستروجين فقط. 
نستخلص من هذا البحث ان هرمون الاستروجين من خلال تتشيط بروتين كينيز C يمكن ان يؤدى الى انخفاض تضخم عضلة البطين الايسر واتساعه. ان هذه النتائج توضح الدور الآيجابى لهرمون الاستروجين لحماية قلوب انثى الفئران من خلد

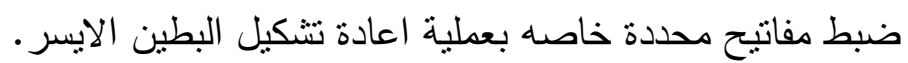

